\title{
John Gibbons, US science adviser, gets high marks for political skills
}

Washington. John Gibbons, named last week as science adviser to President-elect Bill Clinton and director-designate of the White House Office of Science and Technology Policy, fits the dominant profile of those joining the new administration: an experienced and respected administrator, a team player and someone with strong ties to Congress. And while scientists are pleasantly surprised that he was selected as part of the initial round of cabinet appointments, their happiness is tempered by uncertainty about the fate of research under the new administration.

Without exception, those who know the 63-year-old Gibbons and his 13 years as head of the Office of Technology Assessment (OTA) hold both in high regard. "It's a choice made in heaven", says Jeremy Stone, president of the Federation of American Scientists, one of three scientific organizations to have honoured Gibbons recently for outstanding public service (in 1991 the American Physical Society (APS) gave him its Leo Szilard Award, and last year the American Association for the Advancement of Science bestowed its Philip Abelson Prize on him). "He's a perfect match for a president and a vice president who want to understand complex issues, and he's survived the political wars that go along with some of these issues."

Gibbons is a former nuclear physicist turned public servant who is in the midst of his third six-year term as director of OTA, an arm of the US Congress that churns out one major report a week on topics ranging from genetic screening to nuclear weapons. Gibbons is widely credited with rescuing the 20-year-old agency from the political squabbling that crippled it during its early years and turning it into an effective, nonpartisan and parsimonious government agency. His early career was spent at Oak Ridge National Laboratory, studying stellar evolution and the origins of heavy elements in the Solar System. During the 1970s he worked on energy and environmental policy, in particular on conservation and the efficient use of energy.

With Vice President-elect Al Gore expected to be the chief architect of administration policy on science and technology, Gibbons is seen as an excellent choice for a supporting role. "He'll be presenting the options to Al Gore, just as at OTA he presented options to Congress", says APS's Bob Park. Adds Robert Fri, president of
Resources for the Future, an economic think tank in Washington which Gibbons served as a member of the board of directors for nearly a decade, "he's not bland, and he's perfectly capable of speaking his mind. But he's not someone who needs to see his name

technology as a way of strengthening the US economy and improving the country's standard of living. What the new administration has not said, however, is whether that support will come at the expense of basic research.

Last year, Gibbons said that the ultimate rationale for federal spending on basic research is its relevance to broad, national goals. But Gibbons also criticized such expensive scientific projects as the Superconducting Super Collider and the Space Station Freedom - projects with important political constituencies that Clinton and Gore support for "starving" individual investigators in those fields, and he said that reports calling for increased federal spending on research "are simply whistling in the shadow" of the $\$ 350$-billion-a-year federal deficit.

At OTA, Gibbons was adept at combining disparate views and producing reports seen as comprehensive, balanced and useful to policy

and his picture in the newspaper every week."

Although Gibbons has declined to grant interviews since his appointment, he is believed to share Clinton's view that the government should support advanced

\section{Healy: In or out at NIH?}

Washington. One of the more entertaining games for biomedical researchers these days is speculating on whether US Presidentelect Bill Clinton will remove Bernadine Healy as director of the National Institutes of Health (NIH). The heavy betting at this stage is that he will.

In the past few weeks the Clinton transition team has asked a number of prominent research physicians if they would be interested in Healy's job, adding to previous rumours that Clinton plans to replace her. Last week, however, Donna Shalala, his nominee to head the Health and Human Services Department (HHS) of which NIH is a part, told the transition team to stop its inquiries. It is not clear whether that message was an implicit endorsement of the incumbent or merely a sign from Shalala, a member of the NIH director's advisory board, that things were moving too quickly.

No one had reached the top of the list before Shalala's intervention, mainly because the NIH position is not yet a priority for the new administration. And some potential candidates have already said "no thank you". The idea that Healy would be safe because she is a woman has faded in the face of Clinton's appointment of two women (Shalala and Surgeon General-designate Jocelyn Elder) to higher-ranking positions wiithin HHS.

Healy, who joined NIH in April 1991 after her appointment by Republican President George Bush, has not won wide support. Although she took the politically correct route of establishing a multimillion-dollar "women's health initiative", she has failed to win the enduring support of the women's political caucus in Congress. Her conscience-driven but politically risky confrontations with US Representative John Dingell (DemocratMichigan) has put him on her list of enemies. And her "strategic plan" for biomedical research was seen as an attempt to impose NIH as 'Big Brother', weakening her support within a scientific community that, in previous years, has lobbied to keep the NIH director in place during presidential transitions.

Barbara J. Culliton 